\title{
Biology and function of glypican-3 as a candidate for early cancerous transformation of hepatocytes in hepatocellular carcinoma (Review)
}

\author{
MAURO MONTALBANO, JEREMIAS GEORGIADIS, ASHLYN L. MASTERSON, JOSHUA T. McGUIRE, \\ JANIKA PRAJAPATI, ALI SHIRAFKAN, CRISTIANA RASTELLINI and LUCA CICALESE
}

Department of Surgery, University of Texas Medical Branch, Galveston, TX 77555, USA

Received August 8, 2016; Accepted January 12, 2017

DOI: 10.3892/or.2017.5387

\begin{abstract}
Glypican-3 (GPC-3), a transmembrane heparan sulfate proteoglycan (HSPG), has recently been investigated as a player in tissue-dependent cellular signaling, specifically as a regulator of growth. Noteworthy, the regulatory protein has been implicated in both stimulatory and inhibitory pathways involving cell growth. Initially, GPC-3 was thought to act as a cell cycle regulator, as a loss-of-function mutation in the gene caused a hyper-proliferative state known as Simpson-GolabiBehmel (SGB) overgrowth syndrome. Additionally, certain cancer types have displayed a downregulation of GPC-3 expression. More recently, the protein has been evaluated as a useful marker for hepatocellular carcinoma (HCC) due to its increased expression in the liver during times of growth. In contrast, the GPC-3 marker is not detectable in normal adult liver. Immunotherapy that targets GPC-3 and its affiliated proteins is under investigation as these new biomarkers may hold potential for the detection and treatment of HCC and other diseases in which GPC-3 may be overexpressed. Studies have reported that an overexpression of GPC-3 in HCC predicts a poorer prognosis. This prognostic value further pushes the question regarding GPC-3's role in the regulation and progression of HCC. This review will summarize the current knowledge regarding the clinical aspects of GPC-3, while also synthesizing the current literature with the aim to
\end{abstract}

Correspondence to: Professor Luca Cicalese, Department of Surgery, University of Texas Medical Branch, 301 University Boulevard, Galveston, TX 77555, USA

E-mail: lucicale@utmb.edu

Abbreviations: CK19, cytokeratin 19; FGF2, fibroblast growth factor 2; GPC-3, glypican-3; GPI, glycosylphosphatidylinositol; HCC, hepatocellular carcinoma; HPC, hepatic progenitor cell; HSC, heparin sulfate chain; HSPG, heparan sulfate proteoglycan; Hh, hedgehog; IHC, immunohistochemistry; ISH, in situ hybridization; PH, partial hepatectomy; SGB, Simpson-Golabi-Behmel; SULF2, sulfatase 2; sGPC-3N, serum glypican-3 N-terminal; miRNA, microRNA; SCC, squamous cell carcinoma

Key words: glypican-3, hepatocarcinoma, liver, cancer better understand this molecule's biological interactions at a molecular level, not only in the liver, but in the rest of the body as well. Due to the existing gap in the literature surrounding GPC-3, we believe further investigation of function, structure and domains, cellular localization, and other subfields is warranted to evaluate the protein as a whole, as well as its part in the study of HCC.

\section{Contents}

1. Introduction and structure of GPC-3

2. Expression pattern of GPC-3 in human and mouse

3. GPC-3 as a serum marker for early detection of $\mathrm{HCC}$

4. GPC-3 in resection, regeneration and liver diseases

5. GPC-3 as a therapeutic target for HCC

6. GPC-3 and co-receptors

7. Conclusion

\section{Introduction and structure of GPC-3}

The glypicans, a family of proteins classified as HSPGs, have been shown to interact with a number of growth factors and modulate growth factor activity (1) and are linked to the extracellular side of cell membrane by a glycosylphosphatidylinositol (GPI) anchor (2). Members of this large family of transmembrane proteins have been identified in both mammals and drosophila: 6 glypicans (GPC-1 through GPC-6) in mammals, and two others in the fly (2). Glypicans have a core protein size of $\sim 60-70 \mathrm{kDa}$ and express an N-terminal secretory signal peptide along with a hydrophobic domain that is used for the addition of the GPI anchor at the C-terminus. Another characteristic that is shared by all glypicans is the location of the insertion sites for the heparan sulfate chains (HSC), which seems to be restricted to the last 50 amino acids in the $\mathrm{C}$-terminus, placing the chains close to the cell membrane. Additionally, the position of 14 cysteine residues is conserved, further strengthening the structural relationship of the proteins within the family (2).

Much of the literature on GPC-3 stems from its proposed role in vivo as well as in vitro in cancer models. Multiple 
studies have shown a correlation between GPC-3 and hepatocellular carcinoma (HCC) due to the nature of the protein being expressed during normal cellular growth and movement in hepatocytes $(1,3-6)$. In patients who received surgical treatment for HCC, a decrease in GPC-3 protein was observed (3). In addition, in cells derived from hepatocellular carcinoma GPC-3 has been observed to be secreted into culture media (7). GPC-3 does not seems to be expressed by other liver cell types (hepatic stellate cells, kupffer cells, bile duct cells, endothelial cells and fibroblasts) but it appears to be expressed exclusively by hepatocytes. It is well known only that its expression from hepatocytes influences the activity and function of nonparenchymal liver cells.

GPC-3 was initially hypothesized to interact with insulinlike growth factor in selected cell types, though this notion has been challenged as this may not be the case in all cell types (8). In a study done on the loss-of-function mutation of GPC-3 in embryonic development, researchers observed an overgrowth of organs in fetal and postnatal development, known as SimpsonGolabi-Behmel overgrowth syndrome (9). This evidence cast GPC-3 into a strict role as a tumor suppressor. In another study looking at the metastatic adenocarcinoma mammary LM3 cell line, GPC-3 was shown to inhibit the canonical Wnt signals involved in cell proliferation and survival. In the same study, GPC-3 was also observed to play a role in activating the non-canonical Wnt pathway, which directs cell morphology and migration (8). Furthermore, GPC-3 was also found to act as a potential tumor suppressor in lung tissue (10). This has re-opened the case of GPC-3 as a strict suppressor of cell growth and introduced the possibility of its role in stimulating growth and even tumorigenesis in a tissue-dependent manner in some cell lineages.

This being said, certain key elements have been observed which give reason for upregulation of GPC-3 in certain cell types and not others. GPC-3 is able to bind Wnt and Hedgehog (Hh) signaling proteins and was also shown to have the ability to bind basic growth factors such as fibroblast growth factor 2 (FGF2) through its heparan-sulfate glycan chains (11). Additionally, expression of sulfatase 2 (SULF2), another tumor marker expressed in hepatocytes, was found to be correlated with increased expression of GPC-3. When GPC-3 was decreased, FGF2 binding was decreased in SULF2 expressing hepatocellular carcinoma cells. SULF2 expression in resected HCC tissue was also shown to have a worse prognosis and a higher rate of recurrence after surgery (12).

Herein we synthesize the literature on GPC-3, including its structure, expression in normal tissues, as well its role as a serum marker as well as possible therapeutic target. The review also includes current knowledge on GPC-3 expression as a prognostic marker in $\mathrm{HCC}$ and its role in liver regeneration post partial hepatectomy (PH). In addition, we discuss embryonic and adult tissue expression of GPC-3. Lastly, we report the interactions of GPC-3 with CD81 as CD81 has been shown to interact with GPC-3 as a binding partner $(13,14)$.

\section{Expression pattern of GPC-3 in human and mouse}

Embryonic expression of GPC-3. Embryonic expression of GPC-3 differs greatly from the expression map seen in health adult tissues. In most embryonic tissues and organs, there is positive expression of GPC-3 as illustrated by immunohistochemistry (IHC) in humans and in situ hybridization (ISH) in mice. Organs or tissues that display positive expression in human embryonic tissues include: tissues of the digestive tract, the gonads, kidney, limb buds, liver, nerve tissue, oral cavity, pancreas, respiratory syndrome, tongue, and vertebrae (15). In pancreatic tissue, positive expression was seen in exocrine glands, while endocrine glands showed negative expression. In contrast, IHC revealed negative expression of GPC-3 in human embryonic skin tissue (15). Additional detail regarding location and description of GPC-3 expression in human embryonic tissue can be seen in Table I.

Organs or tissues that displayed positive GPC-3 expression in mouse embryonic tissues include: digestive tract, gonads, kidney, limb buds, liver, oral cavity, respiratory system, skin, tongue, and vertebrae $(9,15)$. In contrast, ISH revealed negative expression of GPC-3 in mouse nerve tissue. Pancreas expression in mice was not reported in this study. While GPC-3 expression across mouse and human embryonic tissue appears consistent in most organs, there are some tissues that differ. While nerve tissue shows positive expression in humans, in mice it is not expressed. On the other hand, human tissue is negative for expression of GPC-3 in skin, but this same tissue is positive for the protein in mice (9). Additional detail regarding location and description of GPC-3 expression in mice embryonic tissue can be seen in Table I.

Studies have also shown decreased GPC-3 expression in the SGB overgrowth syndrome, causing a spectrum of congenital defects such as macrosomia, congenital heart disease, conduction defects, supernumerary nipples, diastasis recti/umbilical hernia, diaphragmatic hernia, renal dysplasia/ nephromegaly, cryptorchidism/hypospadias, and hand anomalies (brachydactyly, cutaneous syndactyly, polydactyly) (16). This change in expression and resulting defects are due to a mutation that causes sequence variants as well as multiexon/ whole gene deletion in $37-70 \%$ of male cases $(16,17)$. Table I gives a summary of the SGB syndrome abnormalities found in various organs and tissues as a result of the GPC-3 loss of function mutation $(15,16,18)$. In these cases, GPC-3 acts as a regulator for normal embryonic development and is only found to cause problems in embryonic tissue when it is mutated (Table I).

Expression of GPC-3 in normal adult tissue. Table II summarizes GPC-3 expression in adult tissues normal versus tumor, while Table I summarizes expression of GPC-3 in embryonic tissue in human and mice. As is shown in Table II, the current literature has some contradictions which must be further evaluated to better understand the expression of GPC-3 in tissue types. The tissues represented as having two or more sources contradicting one another in normal tissue (expressed/not expressed) are: gastric glands, kidney tubules, testicular germ cells, breast tissue, gall bladder, and ovary (19-27). In addition, there are also sources reporting no expression, trace amounts, or scarce expression in normal tissue. These tissues are: liver, brain, colon, esophagus, fat tissue, heart, lung, lymph, mouth and associated glandular tissues, pancreas, prostate, skeletal and smooth muscle, small intestine, thyroid and parathyroid, thymus, bladder, and uterus $(2,19,21,22,28-33)$. In Fig. 1, expression of GPC-3 in normal tissue was constructed based 
Table I. GPC-3 expression in human and mouse embryonic tissue.

\begin{tabular}{|c|c|c|c|c|}
\hline Organ & $\begin{array}{l}\text { Embryonic human } \\
\text { staining (IHC) (15) }\end{array}$ & $\begin{array}{l}\text { Embryonic mouse } \\
\text { tissue (ISH) (9) }\end{array}$ & $\begin{array}{c}\text { Additional } \\
\text { description/location } \\
\text { of embryonic expression } \\
\text { of GPC-3 (15) }\end{array}$ & $\begin{array}{c}\text { SGBS abnormalities } \\
(15,16,18)\end{array}$ \\
\hline Digestive tract & Positive expression & Positive expression & $\begin{array}{l}\text { Human: Smooth } \\
\text { muscle and gastric } \\
\text { parietal cells; } \\
\text { Mice: Epithelium only } \\
\text { at } 8.5 \text { days, } \\
\text { submucosal layer }\end{array}$ & $\begin{array}{l}\text { Diastasis recti, } \\
\text { omphalocele and } \\
\text { hernias }\end{array}$ \\
\hline Gonads & $\begin{array}{l}\text { Positive in male } \\
\text { embryos }\end{array}$ & Positive expression & $\begin{array}{l}\text { Human: Leydig cells, } \\
\text { seminiferous } \\
\text { epithelium, urethra, } \\
\text { deferent duct }\end{array}$ & $\begin{array}{l}\text { Cryptorchidism, } \\
\text { reduced penile length, } \\
\text { risk for testicular } \\
\text { gonadoblastoma }\end{array}$ \\
\hline Kidney & Positive expression & Positive expression & $\begin{array}{l}\text { Human: Cortex } \\
\text { convoluted tubules and } \\
\text { Bowman's capsule; } \\
\text { Mice: Mesenchymal }\end{array}$ & $\begin{array}{l}\text { Renal dysplasia, } \\
\text { nephromegaly, risk for } \\
\text { Wilms tumors }\end{array}$ \\
\hline Limb buds & Positive expression & Positive expression & $\begin{array}{l}\text { Human: Mesenchymal } \\
\text { in P1; } \\
\text { Mice: Mesenchymal } \\
\text { from } 9.5 \text { to } 11.5 \text { days } \\
\text { post-coitum. After, only } \\
\text { cartilage precursor of } \\
\text { limb bones }\end{array}$ & Polydactyly, syndactyly \\
\hline Liver & Positive expression & Positive expression & - & Hepatomegaly \\
\hline Nervous system & Positive expression & Negative expression & $\begin{array}{l}\text { Human: Only spinal } \\
\text { cord motoneurons and } \\
\text { dorsal root ganglia } \\
\text { neurons }\end{array}$ & $\begin{array}{l}\text { Hypotony, } \\
\text { developmental delay, } \\
\text { CNS malformations, } \\
\text { and high risk for } \\
\text { neuroblastoma and } \\
\text { medulloblastoma }\end{array}$ \\
\hline Oral cavity & Positive expression & Positive expression & $\begin{array}{l}\text { Human: Palate; } \\
\text { Mice: Epithelium of oral } \\
\text { cavity }\end{array}$ & Cleft palate \\
\hline Pancreas & $\begin{array}{l}\text { Positive/Negative } \\
\text { expression }\end{array}$ & Not reported & $\begin{array}{l}\text { Human: Positive } \\
\text { exocrine in } \mathrm{P} 1 \text { and } \mathrm{P} 2, \\
\text { negative in endocrine }\end{array}$ & $\begin{array}{l}\text { Hyperplastic islets of } \\
\text { Langerhans, } \\
\text { hypoglycemia }\end{array}$ \\
\hline Respiratory system & Positive expression & Positive expression & $\begin{array}{l}\text { Human: Only } \\
\text { mesenchymal cells of } \\
\text { the lungs in P1 and P2; } \\
\text { Mice: Cartilage of } \\
\text { trachea, larynx and } \\
\text { major bronchi, } \\
\text { mesenchymal of lungs }\end{array}$ & Pneumonia \\
\hline Skin & Negative expression & Positive expression & $\begin{array}{l}\text { Mouse: Dermis and } \\
\text { hair follicles }\end{array}$ & None reported \\
\hline Tongue & Positive expression & Positive expression & $\begin{array}{l}\text { Human: Striated } \\
\text { muscle, epithelium, } \\
\text { and connective tissue } \\
\text { of tongue; } \\
\text { Mouse: Only } \\
\text { connective tissue }\end{array}$ & $\begin{array}{l}\text { Macroglossia and } \\
\text { midline groove }\end{array}$ \\
\hline Vertebrae & Positive expression & Positive expression & $\begin{array}{l}\text { Human: Mesenchymal } \\
\text { between caudal } \\
\text { vertebrae; } \\
\text { Mice: Mesenchymal } \\
\text { cells, cartilage and } \\
\text { intervertebral discs }\end{array}$ & Vertebral abnormalities \\
\hline
\end{tabular}




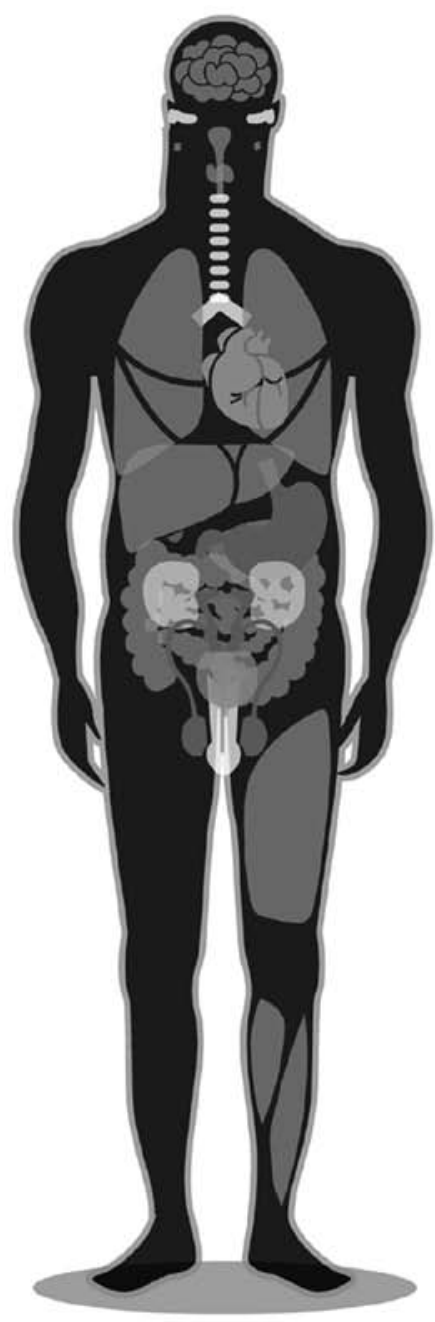

\begin{tabular}{|c|}
\hline BRAIN \\
\hline GASTRIC GLANDS \\
\hline KIDNEY TUBULES \\
\hline TESTICULAR GERM CELLS \\
\hline BREAST TISSUE \\
\hline GUT \\
\hline ESOPHAGUS \\
\hline FAT TISSUE \\
\hline LIVER \\
\hline GALLBLADDER \\
\hline HEART \\
\hline LUNG \\
\hline LYMPH NODES \\
\hline MOUTH and associated tissues \\
\hline OVARY \\
\hline PANCREAS \\
\hline THYMUS, THYROID \& PARATHYYOOIC \\
\hline PROSTATE \\
\hline SKELETAL and SMOOTHMUSCLF \\
\hline SKIN \\
\hline URINARY BLADDER \\
\hline UTERUS \\
\hline
\end{tabular}
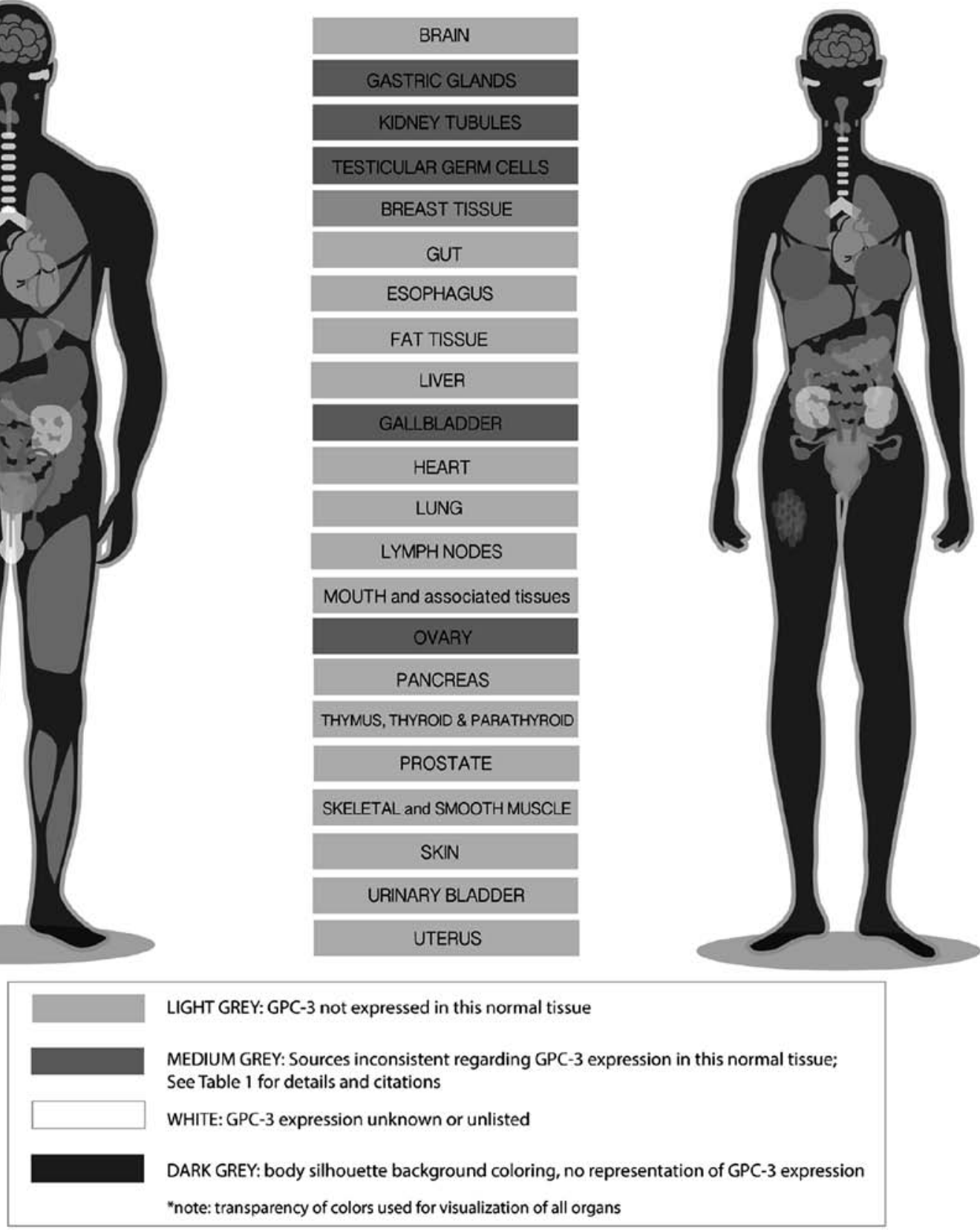

Figure 1. Expression of GPC-3 in normal tissue. The above image was constructed based on Table II. Different grey shades were used to differentiate GPC-3 expression in various tissues. Opacity and transparency of tissues or organs were adjusted for maximized visualization of all organs and their coloring, while retaining anatomical positioning. In organs or tissues colored in light grey (opaque and transparent), GPC-3 is not expressed. In organs or tissues colored in medium grey (opaque and transparent), we found the literature inconsistent regarding GPC-3 expression in those tissues. Table II and its citations for each organ should be referenced for further detail on the nuances of GPC-3 expression in these tissues. Organs or tissues in white (opaque and transparent), expression of GPC-3 was unknown or unfound in the literature. Lastly, the dark grey coloring of the body is simply intended to show the silhouette of body and does not represent any expression of GPC-3.

on Table II. Different grey shades were used to differentiate GPC-3 expression in various tissues.

Expression of GPC-3 in cancer tissue. GPC-3 expression in various types of cancer is not fully understood, though the variance may be due to the specific type of cancer being studied. Table II lists the reported expression of GPC-3 in cancer in various tissue types. Expression of GPC-3 was found in the following cancers: liver, gastric carcinoma, melanoma, highgrade urothelial carcinoma, testicular, and some uterine and vaginal cancers $(1,3-6,23,28,33-35)$. GPC-3 expression was also reported in some non-CNS tumors of the brain (36). In various other tissue types such as colon, lung, anal, esophageal, mouth mucosa, pancreas, skin, thyroid, bladder, uterus, and vulvar tissue GPC-3 expression varied based on the type, and origin, and grade of cancer [i.e. squamous cell carcinoma (SCC) versus mesothelioma of the lung] $(1,10,11,19,28,31-33,37-40)$.

In some cancerous tissues, reduced or even silenced expression of GPC-3 was found; namely renal cell carcinomas, as well as cancer of the breast, ovaries, penis, prostate, and gallbladder $(10,11,24-26,33,38,41,42)$. Similarly, infrequent expression of GPC-3 was reported in some cancers of the 
Table II. GPC-3 expression in adult human tissue types.

\begin{tabular}{|c|c|c|c|}
\hline Tissue & Normal tissue & Cancer tissue & References \\
\hline Liver & Not expressed (28-30) & Expressed $(1,3-6)$ & $1,3-6,28,29,30$ \\
\hline Gastric glands & $\begin{array}{l}\text { Expressed, small subset of } \\
\text { gastric tissues normally express } \\
\text { GPC-3 (19); } \\
\text { Not expressed (20) }\end{array}$ & $\begin{array}{l}\text { Expressed in gastric } \\
\text { carcinoma (34) }\end{array}$ & $19,20,34$ \\
\hline Kidney tubules & $\begin{array}{l}\text { Expressed (19); } \\
\text { Not expressed }(20) ; \\
\text { Low expression }(21,22)\end{array}$ & $\begin{array}{l}\text { Reduced expression in } \\
\text { renal cell carcinoma } \\
\text { ( } 41 \text { mentions renal cell } \\
\text { carcinomas exposed to GPC-3 } \\
\text { caused reduced proliferation); } \\
\text { Infrequent expression in } \\
\text { clear cell carcinoma, } \\
\text { oncocytoma, and papillary } \\
\text { carcinoma of the kidney (19) }\end{array}$ & $19-22,41$ \\
\hline Testicular germ cells & $\begin{array}{l}\text { Expressed (19); } \\
\text { Not expressed (23) }\end{array}$ & Expressed (23) & 19,23 \\
\hline Anus & Unknown & $\begin{array}{l}\text { Expressed (33); } \\
\text { Infrequent expression in SCC (19) }\end{array}$ & 19,33 \\
\hline Breast tissue & $\begin{array}{l}\text { Not expressed (19); } \\
\text { Expressed (24); } \\
\text { Expressed (25) }\end{array}$ & $\begin{array}{l}\text { Reduced expression (24) } \\
\text { Silenced (25); } \\
\text { Infrequent expression in } \\
\text { invasive ductal and } \\
\text { tubular carcinoma (19) }\end{array}$ & $19,24,25$ \\
\hline Brain & Not expressed (19) & $\begin{array}{l}\text { Expressed in some non-CNS } \\
\text { tumors and restricted expression } \\
\text { in atypical teratoid rhabdoid } \\
\text { tumors and in some } \\
\text { craniopharyngiomas (36) }\end{array}$ & 19,36 \\
\hline Colon & $\begin{array}{l}\text { Not expressed }(2,19) \text {; } \\
\text { Trace amounts expressed }(21,22)\end{array}$ & $\begin{array}{l}\text { Expressed }(1,37) \text {; } \\
\text { Infrequent expression in } \\
\text { adenocarcinoma and } \\
\text { adenoma with high-grade } \\
\text { dysplasia (19) }\end{array}$ & $1,2,19,21,22,37$ \\
\hline Esophagus & Not expressed $(31,19)$ & $\begin{array}{l}\text { Expressed }(31,33) ; \\
\text { Infrequent expression in } \\
\text { squamous cell carcinoma (19) }\end{array}$ & $19,31,33$ \\
\hline Fat tissue & Not expressed (19) & Unknown & 19 \\
\hline Gallbladder & $\begin{array}{l}\text { Not expressed (19); } \\
\text { Expressed (26) }\end{array}$ & $\begin{array}{l}\text { Reduced expression in } \\
\text { gallbladder cancer (26); } \\
\text { Infrequent expression in } \\
\text { adenocarcinoma (19) }\end{array}$ & 19,26 \\
\hline Heart & $\begin{array}{l}\text { Not expressed }(19) ; \\
\text { Low expression }(21,22)\end{array}$ & Unknown & $19,21,22$ \\
\hline Lung & $\begin{array}{l}\text { Not expressed }(19) ; \\
\text { Low expression }(21,22)\end{array}$ & $\begin{array}{l}\text { Silenced in mesothelioma } \\
\text { and lung adenocarcinoma } \\
(10,11,38) ; \\
\text { Expressed in lung squamous } \\
\text { cell carcinoma (39); } \\
\text { Expressed (33); } \\
\text { Infrequent expression in } \\
\text { adenocarcinoma and } \\
\text { large cell carcinoma (19) }\end{array}$ & $10,11,19,21,22,33,38,39$ \\
\hline Lymph nodes & Not expressed (19) & Unknown & 19 \\
\hline Mouth (mucosa) & Not expressed (19) & $\begin{array}{l}\text { Expressed on some tongue, } \\
\text { base/tonsil, ventral tongue/ } \\
\text { floor of mouth (33); } \\
\text { Infrequent expression in } \\
\text { squamous cell carcinoma (19) }\end{array}$ & 19,33 \\
\hline
\end{tabular}


Table II. Continued.

\begin{tabular}{|c|c|c|c|}
\hline Tissue & Normal tissue & Cancer tissue & References \\
\hline Ovary & $\begin{array}{l}\text { Not expressed }(19) ; \\
\text { Low expression }(21,22) ; \\
\text { Expressed }(27)\end{array}$ & $\begin{array}{l}\text { Silenced in epithelial } \\
\text { ovarian cancer }(10,11,25,38) ; \\
\text { Infrequent expression in } \\
\text { Brenner tumor, endometrioid } \\
\text { carcinoma, mucinous carcinoma, } \\
\text { serous carcinoma, and } \\
\text { yolk sac tumor }(19) ; \\
\text { No expression }(27)\end{array}$ & $10,11,19,21,22,25,27,38$ \\
\hline Pancreas & $\begin{array}{l}\text { Not expressed (19); } \\
\text { Trace amounts expressed } \\
(21,22)\end{array}$ & $\begin{array}{l}\text { Expressed ( } 31) \text {; } \\
\text { No expression in pancreatic } \\
\text { adenocarcinoma }(40)\end{array}$ & $19,21,22,31,40$ \\
\hline Parathyroid & Not expressed (19) & Unknown & 19 \\
\hline Parotid gland & Not expressed (19) & Unknown & 19 \\
\hline Penis & Unknown & $\begin{array}{l}\text { No expression in squamous } \\
\text { cell carcinoma (33); } \\
\text { Infrequent expression } \\
\text { in SCC (19) }\end{array}$ & 19,33 \\
\hline Prostate & Not expressed (19) & $\begin{array}{l}\text { Infrequent expression } \\
\text { in adenocarcinoma (19); } \\
\text { No expression (42) }\end{array}$ & 19,42 \\
\hline Skeletal muscle & $\begin{array}{l}\text { Not expressed }(19) \text {; } \\
\text { Trace amounts expressed }(21,22)\end{array}$ & $\begin{array}{l}\text { Infrequent expression in } \\
\text { rhabdomyosarcoma (19) }\end{array}$ & $19,21,22$ \\
\hline Skin & Not expressed (19) & $\begin{array}{l}\text { No expression in squamous } \\
\text { cell carcinoma (33); } \\
\text { Expression in melanoma (28) }\end{array}$ & 19,33 \\
\hline Small intestine (mucosa) & $\begin{array}{l}\text { Not expressed (19); } \\
\text { Trace amounts expressed }(21,22)\end{array}$ & $\begin{array}{l}\text { Infrequent expression in } \\
\text { adenocarcinoma and } \\
\text { gastrointestinal stromal tumor (19) }\end{array}$ & $19,21,22$ \\
\hline Smooth muscle & Not expressed (19) & $\begin{array}{l}\text { Infrequent expression in } \\
\text { leiomyosarcoma (19) }\end{array}$ & 19 \\
\hline Submandibular gland & Not expressed (19) & $\begin{array}{l}\text { Infrequent expression in } \\
\text { acinar cell carcinoma, } \\
\text { adenoid cystic carcinoma, } \\
\text { and small cell carcinoma (19) }\end{array}$ & 19 \\
\hline Thymus & Not expressed (19) & Unknown & 19 \\
\hline Thyroid & $\begin{array}{l}\text { Not expressed (19); } \\
\text { Scarcely expressed (32) }\end{array}$ & $\begin{array}{l}\text { Infrequent expression in } \\
\text { papillary carcinoma (19); } \\
\text { Expressed in early papillary } \\
\text { carcinoma (32) }\end{array}$ & 19,32 \\
\hline Urinary bladder & Not expressed $(19,33)$ & $\begin{array}{l}\text { Expressed (33); } \\
\text { Expressed in urothelial } \\
\text { carcinoma, mostly in } \\
\text { high grade tumors }(35) ; \\
\text { Infrequent expression in } \\
\text { noninvasive transitional } \\
\text { cell carcinoma, small } \\
\text { cell carcinoma, and } \\
\text { squamous cell carcinoma (19) }\end{array}$ & $19,33,35$ \\
\hline $\begin{array}{l}\text { Uterus (cervix, } \\
\text { endometrium, } \\
\text { myometrium) }\end{array}$ & Not expressed (19) & $\begin{array}{l}\text { Expressed (33); } \\
\text { Infrequent expression in } \\
\text { cervix as SCC and } \\
\text { endometrium as endometrioid } \\
\text { and serous carcinoma (19) }\end{array}$ & 19,33 \\
\hline Vagina & Unknown & Expressed (33) & 33 \\
\hline Vulva & Unknown & $\begin{array}{l}\text { No expression in squamous } \\
\text { cell carcinoma ( } 33) ; \\
\text { Expression in some } \\
\text { tumors analyzed in SCC (19) }\end{array}$ & 19,33 \\
\hline
\end{tabular}


kidney, invasive ductal and tubular carcinomas of the breast, some brain tumors, adenocarcinomas of the gall bladder, prostate, and small intestine, squamous cell carcinoma of the penis, rhabdosarcomas and leimyosarcomas of the skeletal and smooth muscle, adeno- and small cell carcinomas of the submandibular glands, among other cancerous tissues depending upon grade and location within the tissue $(19,33,36)$. For more detail regarding GPC-3 expression in these tissues, refer to Table II.

In human breast cancer, GPC-3 has been shown to be silenced due to hypermethylation of its promoter region. The data also suggest that GPC-3 can act as a negative regulator of breast cancer growth as well a downregulator in mesotheliomas and ovarian cancer (25). Xq26 is a region frequently deleted in advanced ovarian cancers and is where the GPC-3 gene is located.

In ovarian cancer, GPC-3 expression was lost in cell lines analyzed which was also due to hypermethylation of the promoter region. Expression of GPC-3 was restored with the treatment of 5-aza-2'-deoxycytidinem, a demethylating agent. Ectopic GPC-3 expression inhibited the growth of ovarian cancer cell lines and results show that GPC-3 is frequently inactivated in a subset of ovarian cancers which may suggest that it functions as a tumor suppressor in the ovary (27).

In $15 \%$ or more of studied cases, GPC-3 was expressed in tumor types of hepatocellular carcinoma, squamous cell carcinoma of the lung, liposarcoma, testicular nonseminomatous germ cell tumor, cervical intraepithelial neoplasia (grade 3), malignant melanoma, adenoma of the adrenal gland, schwannoma, malignant fibrous histiocytoma, adenocarcinoma of the stomach (intestinal subtype), chromophobe renal cell carcinoma, invasive lobular carcinoma of the breast, medullary carcinoma of the breast, squamous cell carcinoma of the larynx, small cell carcinoma of the lung, invasive transitional cell carcinoma of the urinary bladder, mucinous carcinoma of the breast, and squamous cell carcinoma of the cervix (19).

\section{GPC-3 as a serum marker for early detection of HCC}

GPC-3 may be a potential serum marker in diseases such as HCC in which expression of GPC-3 is markedly increased (20,21). Capurro et al examined GPC-3 protein expression and serum levels using immunohistochemistry and ELISA in HCC patients, as well as serum levels in healthy donors and patients with hepatitis and liver cirrhosis. Results revealed increased GPC-3 expression levels in patients with HCC, but not in healthy hepatocytes. GPC-3 serum levels were significantly elevated in $\mathrm{HCC}$ patients, but undetectable in the serum of healthy and hepatitis-infected patients (22).

Discussing where this protein is cleaved, the cleaved portion of the $\mathrm{NH}(2)$-terminal was found to be between $\operatorname{Arg}(358)$ and Ser(359) of GPC-3. In addition to this, it was observed that soluble GPC-3 can be specifically detected in the sera of patients with HCC using N-mAbs (23). Unfortunately, the cleavage events and other post-translational modifications are understudied. It is necessary to investigate in terms of function and cellular localization the cleavage events on GPC-3. Focusing on serum marker it is necessary to understand if the protein is cleaved and which portion is secreted improving the knowledge of secretory pathways involved in its sorting in and out of the cells, with major attention on exosomal cargos.

GPC-3 was also identified as a novel diagnostic marker for human melanoma it its early stages. In patients with melanoma, GPC was detected. However, the protein was not found in the sera of healthy patients, or those with benign skin lesions (large congenital melanocytic nevus). It was also detected in the serum of patients with stage 0 , in situ melanoma (28).

In another study carried out to observe biomarkers for HCC, preoperative serum GPC-3-N (sGPC-3N) levels were measured alongside with serum AFP in patients with HCC. It was observed that high serum AFP corresponded with a high sGPC-3N level. The study states that sGPC-3N may serve as an independent prognostic biomarker in HCC patients (24).

Serum $\alpha$-fetoprotein is the common diagnostic marker to detect HCC. Several studies showed that the combination of $\alpha$-fetoprotein and GPC-3 increase significantly the sensitivity of diagnostic value compared to their sensitivity analyzed independently (43). Several markers are under investigation to ameliorate the sensitivity and specificity of HCC detection such as: des- $\gamma$ carboxyprothrombin, lens culinaris agglutininreactive $\alpha$-fetoprotein, Golgi protein $73(43,44)$. However, GPC-3 seems to be more specific due to its peculiar expression in hepatocytes as showed before, and this represents the main advantage for its use in HCC detection even if its mechanism of transport in the serum is still unknown. For its peculiar localization and post-translational modifications GPC-3 could represent an ideal target for antibody therapeutic approach with the possibility to bind its membrane form thus inhibiting its activity. Moreover, a chemical approach could obtain the cleavage events that determine GPC-3 functional modulation and cellular localization. Consequent to its expression in preneoplastic hepatocytes, this offers the unique advantage of allowing an early and specific therapeutic approach.

\section{GPC-3 in resection, regeneration and liver diseases}

Few studies have demonstrated the expression of GPC-3 pre- and post-hepatic resection. Due to hepatic progenitor cells expressing cytokeratin 19 (CK19) and GPC-3 at varying phenotypes, cell samples were analyzed from patients who had a liver resection and were statistically compared with each phenotype of expression in Table III. It was found that CK19+/ GPC $-3^{+}$HCC was the most aggressive subtype, followed by the $\mathrm{CK} 19^{-} / \mathrm{GPC}^{-} 3^{+} \mathrm{HCC}$ and finally with the CK19-/GPC-3HCC subtype being the least aggressive from the subtypes observed (45). Therefore, a poorer prognosis may be associated with patients undergoing a hepatectomy who have the expression of both CK19 and GPC-3.

Liu et al, on the other hand, described transgenic GPC-3 mice, which were under the control of the albumin promoter gene, overexpressed GPC-3 and actually had a suppression of hepatocyte proliferation and liver regeneration following partial hepatectomy $(30,46)$. These mice developed normally and the authors claim that GPC-3 may play a negative regulatory role in hepatocyte proliferation, showing a contrasting role of GPC-3 in the hepatocytes. Further investigation using models post-PH is needed to uncover various important aspects of GPC-3 expression such as the density and location 
Table III. Phenotype of expression (25).

\begin{tabular}{lcl}
\hline $\begin{array}{l}\text { Order of } \\
\text { severity }\end{array}$ & $\begin{array}{c}\text { Cell marker phenotype } \\
\text { CK19/GPC-3 HCC }\end{array}$ & \multicolumn{1}{c}{ Cell marker description } \\
\hline 1 & ++ & HCC subtype transformed from hepatic progenitor cells (HPC) \\
2 & -+ & Immature hepatocyte \\
3 & -- & Terminal differentiated hepatocyte \\
\hline
\end{tabular}

of GPC-3 expression (i.e. the cut margin or other location). This research may be instrumental in further elucidation of the role and mechanisms of GPC-3 in liver growth and regeneration post-resection and even injury (mechanically, inflammatory, or otherwise). However, limited studies have been conducted on the regeneration of the liver.

At this time there is no evidence on a possible function and presence of GPC-3 in other liver diseases such as fibrosis, fatty liver disease or liver cirrhosis. The peculiarity of its expression in neoplastic hepatocytes makes GPC-3 not only a unique HCC marker but also a possible therapeutic target. However, studies in cirrhotic livers without $\mathrm{HCC}$ are necessary to rule out the role of GPC-3 or the presence in these circumstances.

\section{GPC-3 as a therapeutic target for HCC}

Therapeutic targets are especially important in the treatment of various types of cancer. GC33, which is a humanized monoclonal antibody, was shown to bind human GPC-3. GC33 has been observed to contain antitumor properties and targets GPC-3 specifically. It was noted that GC33 was well tolerated in advanced HCC and provided some benefit in the clinical treatment (47). In addition, human (MDX-1414 and HN3) and humanized mouse (GC33 and YP7) antibodies that also target GPC-3 are under different stages of clinical development and could also aid in the treatment of HCC (21). miR-219-5p is a microRNA (miRNA) which could exert tumor suppression on hepatic cells expressing GPC-3. miR-219-5p reduced both the mRNA and protein levels of GPC-3 and exerted tumorsuppressive effects in HCC (48). Finally, nanoparticles are also under development to target and bind GPC-3 in cells that could provide useful for further imaging and targeting of GPC-3 (49).

Research has also been conducted in regards to peptide sequences which bind GPC-3. Feng et al described a 12-mer peptide sequence (DHLASLWWGTEL) which was able to act as a probe and bind GPC-3 for HCC detection (21). The peptide allows visualization of the specific sequence via near-infrared fluorescence (50). Another therapeutic target on GPC-3 is mir717, a miRNA, which is located on intron 3 of GPC-3 on the $\mathrm{X}$ chromosome. It has been shown to play a regulatory role in renal osmoregulation. mir717 might be connected in some way with obesity regulation, one of the risk factors of $\operatorname{HCC}(51,52)$.

It has been proposed that GPC-3 acts as a negative regulator in the Hedgehog signaling pathway during development and as a result, a non-functional GPC-3 protein could be the cause of overgrowth or a GPC 3 modified by post-translational modifications. GPC-3 has also been associated with the binding of Wnt to its signaling receptor, Frizzled (53-56). Both the Hh and canonical/non-canonical pathways of Wnt could be potential therapeutic targets as GPC-3 may play a role in proliferation and/or growth suppression, depending on the type of tissue and the stage of development $(8,57)$. In addition, the peptide sequences Arg-Leu-Asn-Val-Gly-Gly-Thr-Tyr-Phe-Leu-ThrThr-Arg-Gln and Tyr-Phe-Leu,Thr-Thr-Arg-Gln showed selective binding of GPC-3 (58) which could provide useful for a target that is needing to bind onto GPC-3 for regulation.

\section{GPC-3 and co-receptors}

GPC-3 has been observed to interact with a number of co-receptors that further modulate cellular expression. Liu et al showed that GPC-3 and CD81 levels were significantly upregulated in general in the transgenic mice following partial hepatectomy $(30,46)$. They showed that the negative regulatory role was somehow associated with GPC-3 and CD81 and that there is enhanced association between GPC-3 and CD81. GPC-3 and CD81 have both been associated as binding partners in which expression could influence the Hh (13). Co-localization of GPC-3 and CD81 was also shown to occur 2-6 days after hepatectomy (30). In contrast, another study observed that GPC-3 binds to members of the Hh pathway and prevents their interactions with the patched-1 receptor. There was decreased binding of GPC-3 with $\mathrm{Hh}$ and CD81 following PH and GPC-3/CD81 may play a role in the termination of liver growth following liver regeneration $(14,46)$. Dysregulation of the association between GPC-3/CD81, which may occur during hepatitis $\mathrm{C}$ infection can result in dysregulated signaling and proliferation in infected hepatocytes (59). The structure and character of GPC-3 as a transmembrane protein, in conjunction with the current literature, lends itself to the strong possibility of many associations or interactions with other co-receptors and proteins, not only in hepatocytes, but possible in other normal or cancerous tissue types. It is important to emphasize again the paucity in the current literature in regard to this, and many other aspects of GPC-3.

\section{Conclusion}

GPC-3 is a molecule that is still not fully understood in its role in the proliferation and suppression of cell growth in normal and abnormal or cancerous tissue and also in structural and post-translational modifications. The question still remains as to why it is normally expressed in some tissues, while remaining silenced in others. Future research that looks into the upstream and downstream cell signaling pathways and how GPC-3 may be involved could provide further answers. In addition, studies investigating a more complete picture and 
analysis of GPC-3 structure are warranted, as glycosylation, sulfonation, or other structural components of the protein may be important in understanding its regulatory function within differing tissue types. In this same vein, continued insight into the cleavage of GPC-3 and the function of the cleaved versus non-cleaved form of the molecule could lead to a more complete comprehension of function. Other research paths may include developing the theory of GPC-3 as a dual tumor suppressor and oncogene, as dependent upon its structure. With exosome research brightening the horizons, more attention and detail must be paid to uncover the importance of exosomal GPC-3 as a serum marker or as possible therapeutic target in HCC. GPC-3 is a molecule that could further connect the missing links in liver cancer research and lead to an abundance of new intercellular relationships to reveal important aspects of the biology of this disease.

\section{References}

1. Midorikawa Y, Ishikawa S, Iwanari H, Imamura T, Sakamoto H, Miyazono K, Kodama T, Makuuchi M and Aburatani $\mathrm{H}$ : Glypican-3, overexpressed in hepatocellular carcinoma, modulates FGF2 and BMP-7 signaling. Int J Cancer 103: $455-465,2003$

2. Filmus J and Selleck SB: Glypicans: Proteoglycans with a surprise. J Clin Invest 108: 497-501, 2001.

3. Nakatsura T, Yoshitake Y, Senju S, Monji M, Komori H, Motomura Y, Hosaka S, Beppu T, Ishiko T, Kamohara H, et al Glypican-3, overexpressed specifically in human hepatocellular carcinoma, is a novel tumor marker. Biochem Biophys Res Commun 306: 16-25, 2003.

4. Wang XY, Degos F, Dubois S, Tessiore S, Allegretta M, Guttmann RD, Jothy S, Belghiti J, Bedossa P and Paradis V: Glypican-3 expression in hepatocellular tumors: Diagnostic value for preneoplastic lesions and hepatocellular carcinomas. Hum Pathol 37: 1435-1441, 2006.

5. Montalbano M, Rastellini C, Wang X, Corsello T, Eltorky MA, Vento R and Cicalese L: Transformation of primary human hepatocytes in hepatocellular carcinoma. Int J Oncol 48: 1205-1217, 2016.

6. Montalbano M, Curcurù G, Shirafkan A, Vento R, Rastellini C and Cicalese L: Modeling of hepatocytes proliferation isolated from proximal and distal zones from human hepatocellular carcinoma lesion. PLoS One 11: e0153613, 2016.

7. Sung YK, Hwang SY, Park MK, Farooq M, Han IS, Bae HI, Kim JC and Kim M: Glypican-3 is overexpressed in human hepatocellular carcinoma. Cancer Sci 94: 259-262, 2003.

8. Stigliano I, Puricelli L, Filmus J, Sogayar MC, Bal de Kier Joffé E and Peters MG: Glypican-3 regulates migration, adhesion and actin cytoskeleton organization in mammary tumor cells through Wnt signaling modulation. Breast Cancer Res Treat 114: 251-262, 2009.

9. Pellegrini M, Pilia G, Pantano S, Lucchini F, Uda M, Fumi M, Cao A, Schlessinger D and Forabosco A: Gpc3 expression correlates with the phenotype of the Simpson-Golabi-Behmel syndrome. Dev Dyn 213: 431-439, 1998.

10. Kim H, Xu GL, Borczuk AC, Busch S, Filmus J, Capurro M, Brody JS, Lange J, D'Armiento JM, Rothman PB, et al: The heparan sulfate proteoglycan GPC3 is a potential lung tumor suppressor. Am J Respir Cell Mol Biol 29: 694-701, 2003.

11. Ho M and Kim H: Glypican-3: A new target for cancer immunotherapy. Eur J Cancer 47: 333-338, 2011.

12. Lai JP, Sandhu DS, Yu C, Han T, Moser CD, Jackson KK, Guerrero RB, Aderca I, Isomoto H, Garrity-Park MM, et al: Sulfatase 2 up-regulates glypican 3, promotes fibroblast growth factor signaling, and decreases survival in hepatocellular carcinoma. Hepatology 47: 1211-1222, 2008.

13. Bhave VS, Mars W, Donthamsetty S, Zhang X, Tan L, Luo J, Bowen WC and Michalopoulos GK: Regulation of liver growth by glypican 3, CD81, hedgehog, and Hhex. Am J Pathol 183: $153-159,2013$.

14. Michalopoulos GK: Regenerative responses to liver injury. Eur J Med Res 19 (Suppl 1): S1, 2014. doi: 10.1186/2047-783X-19-S1-S1.
15. Iglesias BV, Centeno G, Pascuccelli H, Ward F, Peters MG, Filmus J, Puricelli L and de Kier Joffé EB: Expression pattern of glypican-3 (GPC3) during human embryonic and fetal development. Histol Histopathol 23: 1333-1340, 2008.

16. Golabi M, Leung A and Lopez C: Simpson-Golabi-Behmel syndrome type 1. In: GeneReviews ${ }^{\circledR}$. [Internet]. Pagon RA, Adam MP, Ardinger HH, et al (eds). University of Washington, Seattle, Seattle, WA, pp1993-2016, 2006. Last update: June 23, 2011.

17. Khan S, Blackburn M, Mao DL, Huber R, Schlessinger D and Fant M: Glypican-3 (GPC3) expression in human placenta: Localization to the differentiated syncytiotrophoblast. Histol Histopathol 16: 71-78, 2001.

18. DeBaun MR, Ess J and Saunders S: Simpson Golabi Behmel syndrome: Progress toward understanding the molecular basis for overgrowth, malformation, and cancer predisposition. Mol Genet Metab 72: 279-286, 2001.

19. Baumhoer D, Tornillo L, Stadlmann S, Roncalli M, Diamantis EK and Terracciano LM: Glypican 3 expression in human nonneoplastic, preneoplastic, and neoplastic tissues: A tissue microarray analysis of 4,387 tissue samples. Am J Clin Pathol 129: 899-906, 2008.

20. Gao H, Li K, Tu H, Pan X, Jiang H, Shi B, Kong J, Wang H, Yang S, Gu J, et al: Development of $\mathrm{T}$ cells redirected to glypican-3 for the treatment of hepatocellular carcinoma. Clin Cancer Res 20: 6418-6428, 2014.

21. Feng $M$ and Ho M: Glypican-3 antibodies: A new therapeutic target for liver cancer. FEBS Lett 588: 377-382, 2014.

22. Hsu HC, Cheng W and Lai PL: Cloning and expression of a developmentally regulated transcript MXR7 in hepatocellular carcinoma: Biological significance and temporospatial distribution. Cancer Res 57: 5179-5184, 1997.

23. Zynger DL, Dimov ND, Luan C, Teh BT and Yang XJ: Glypican 3: A novel marker in testicular germ cell tumors. Am J Surg Pathol 30: 1570-1575, 2006.

24. Castillo L, Huvelle MAL, Fujita A, Lobba ARM, Tascon R and Peters MG: Expression of glypican-3 (GPC3) in malignant and non-malignant human breast tissues. Open Cancer J 8: 12-23, 2015. https://benthamopen.com/contents/pdf/TOCJ/TOCJ-8-12.pdf

25. Xiang YY, Ladeda V and Filmus J: Glypican-3 expression is silenced in human breast cancer. Oncogene 20: 7408-7412, 2001.

26. Man XB, Tang L, Zhang BH, Li SJ, Qiu XH, Wu MC and Wang HY: Upregulation of Glypican-3 expression in hepatocellular carcinoma but downregulation in cholangiocarcinoma indicates its differential diagnosis value in primary liver cancers. Liver Int 25: 962-966, 2005.

27. Lin H, Huber R, Schlessinger D and Morin PJ: Frequent silencing of the GPC3 gene in ovarian cancer cell lines. Cancer Res 59: 807-810, 1999 .

28. Nakatsura T, Kageshita T, Ito S, Wakamatsu K, Monji M, Ikuta Y, Senju S, Ono T and Nishimura Y: Identification of glypican-3 as a novel tumor marker for melanoma. Clin Cancer Res 10: 6612-6621, 2004

29. Luo JH, Ren B, Keryanov S, Tseng GC, Rao UN, Monga SP, Strom S, Demetris AJ, Nalesnik M, Yu YP, et al: Transcriptomic and genomic analysis of human hepatocellular carcinomas and hepatoblastomas. Hepatology 44: 1012-1024, 2006.

30. Liu B, Paranjpe S, Bowen WC, Bell AW, Luo JH, Yu YP, Mars WM and Michalopoulos GK: Investigation of the role of glypican 3 in liver regeneration and hepatocyte proliferation. Am J Pathol 175: 717-724, 2009.

31. Ahmed SS, Ola A, Ahmed E and Mohammed A: Seroprevalence of Glypican-3 (GPC-3) in patients with pancreatic, gastric and esophageal cancers. NY Sci J 4: 45-50, 2011. http://www. sciencepub.net/newyork/ny0407/08_6074ny0407_45_50.pdf

32. Yamanaka K, Ito $Y$, Okuyama $\bar{N}$, Noda $K$, Matsumoto $H$, Yoshida H, Miyauchi A, Capurro M, Filmus J and Miyoshi E: Immunohistochemical study of glypican 3 in thyroid cancer. Oncology 73: 389-394, 2007.

33. Gailey MP and Bellizzi AM: Immunohistochemistry for the novel markers glypican 3 , PAX8, and p40 $(\Delta$ Np63) in squamous cell and urothelial carcinoma. Am J Clin Pathol 140: 872-880, 2013.

34. Ushiku T,UozakiH, Shinozaki A, Ota S, Matsuzaka K, Nomura S, Kaminishi M, Aburatani H, Kodama $\mathrm{T}$ and Fukayama M: Glypican 3-expressing gastric carcinoma: Distinct subgroup unifying hepatoid, clear-cell, and alpha-fetoprotein-producing gastric carcinomas. Cancer Sci 100: 626-632, 2009.

35. Aydin O, Yildiz L, Baris S, Dundar C and Karagoz F: Expression of Glypican 3 in low and high grade urothelial carcinomas. Diagn Pathol 10: 34, 2015. 
36. Chan ES, Pawel BR, Corao DA, Venneti S, Russo P, Santi M and Sullivan LM: Immunohistochemical expression of glypican-3 in pediatric tumors: An analysis of 414 cases. Pediatr Dev Pathol 16: 272-277, 2013.

37. Gonzalez AD, Kaya M, Shi W, Song H, Testa JR, Penn LZ and Filmus J: OCI-5/GPC3, a glypican encoded by a gene that is mutated in the Simpson-Golabi-Behmel overgrowth syndrome, induces apoptosis in a cell line-specific manner. J Cell Biol 141: 1407-1414, 1998.

38. Murthy SS, Shen T, De Rienzo A, Lee WC, Ferriola PC, Jhanwar SC, Mossman BT, Filmus J and Testa JR: Expression of GPC3, an X-linked recessive overgrowth gene, is silenced in malignant mesothelioma. Oncogene 19: 410-416, 2000.

39. Yu X, Li Y, Chen SW, Shi Y and Xu F: Differential expression of glypican-3 (GPC3) in lung squamous cell carcinoma and lung adenocarcinoma and its clinical significance. Genet Mol Res 14: 10185-10192, 2015.

40. Mounajjed T, Zhang L and Wu TT: Glypican-3 expression in gastrointestinal and pancreatic epithelial neoplasms. Hum Pathol 44: 542-550, 2013.

41. Valsechi MC, Oliveira AB, Conceição AL, Stuqui B, Candido NM, Provazzi PJ, de Araújo LF, Silva WA Jr, Calmon Mde F and Rahal P: GPC3 reduces cell proliferation in renal carcinoma cell lines. BMC Cancer 14: 631, 2014.

42. Zhang L, Liu H, Sun L, Li N, Ding H and Zheng J: Glypican-3 as a potential differential diagnosis marker for hepatocellular carcinoma: A tissue microarray-based study. Acta Histochem 114: 547-552, 2012.

43. Huang TS, Shyu YC, Turner R, Chen HY and Chen PJ: Diagnostic performance of alpha-fetoprotein, lens culinaris agglutininreactive alpha-fetoprotein, des-gamma carboxyprothrombin, and glypican-3 for the detection of hepatocellular carcinoma: A systematic review and meta-analysis protocol. Syst Rev 2: 37, 2013.

44. Wang Y, Yang H, Xu H, Lu X, Sang X, Zhong S, Huang J and Mao Y: Golgi protein 73, not Glypican-3, may be a tumor marker complementary to $\alpha$-Fetoprotein for hepatocellular carcinoma diagnosis. J Gastroenterol Hepatol 29: 597-602, 2014.

45. Feng J, Zhu R, Chang C, Yu L, Cao F, Zhu G, Chen F, Xia H, Lv F, Zhang S, et al: CK19 and Glypican 3 expression profiling in the prognostic indication for patients with $\mathrm{HCC}$ after surgical resection. PLoS One 11: e0151501, 2016.

46. Liu B, Bell AW, Paranjpe S, Bowen WC, Khillan JS, Luo JH, Mars WM and Michalopoulos GK: Suppression of liver regeneration and hepatocyte proliferation in hepatocyte-targeted glypican 3 transgenic mice. Hepatology 52: 1060-1067, 2010.
47. Zhu AX, Gold PJ, El-Khoueiry AB, Abrams TA, Morikawa H, Ohishi N, Ohtomo T and Philip PA: First-in-man phase I study of GC33, a novel recombinant humanized antibody against glypican-3, in patients with advanced hepatocellular carcinoma. Clin Cancer Res 19: 920-928, 2013.

48. Huang N, Lin J, Ruan J, Su N, Qing R, Liu F, He B, Lv C, Zheng D and Luo R: MiR-219-5p inhibits hepatocellular carcinoma cell proliferation by targeting glypican-3. FEBS Lett 586: 884-891, 2012.

49. Park JO, Stephen Z, Sun C, Veiseh O, Kievit FM, Fang C, Leung M, Mok $\mathrm{H}$ and Zhang M: Glypican-3 targeting of liver cancer cells using multifunctional nanoparticles. Mol Imaging 10: 69-77, 2011.

50. Zhu D, Qin Y, Wang J, Zhang L, Zou S, Zhu X and Zhu L: Novel glypican-3-binding peptide for in vivo hepatocellular carcinoma fluorescent imaging. Bioconjug Chem 27: 831-839, 2016.

51. Kunej T, Skok DJ, Horvat S, Dove P and Jiang Z: The glypican 3-hosted murine mir717 gene: Sequence conservation, seed region polymorphisms and putative targets. Int J Biol Sci 6: 769-772, 2010

52. Kew MC: Obesity as a cause of hepatocellular carcinoma. Ann Hepatol 14: 299-303, 2015.

53. Filmus $\mathrm{J}$ and Capurro M: The role of glypican-3 in the regulation of body size and cancer. Cell Cycle 7: 2787-2790, 2008

54. Filmus J and Capurro M: Glypican-3: A marker and a therapeutic target in hepatocellular carcinoma. FEBS J 280: 2471-2476, 2013.

55. Tsuda M, Kamimura K, Nakato H, Archer M, Staatz W, Fox B, Humphrey M, Olson S, Futch T, Kaluza V, et al: The cell-surface proteoglycan Dally regulates Wingless signalling in Drosophila. Nature 400: 276-280, 1999.

56. Song HH, Shi W, Xiang YY and Filmus J: The loss of glypican-3 induces alterations in Wnt signaling. J Biol Chem 280: 2116-2125, 2005.

57. Capurro MI, Xiang YY, Lobe C and Filmus J: Glypican-3 promotes the growth of hepatocellular carcinoma by stimulating canonical Wnt signaling. Cancer Res 65: 6245-6254, 2005.

58. Lee YL, Ahn B-C, Lee Y, Lee S-W, Cho J-Y and Lee J: Targeting of hepatocellular carcinoma with glypican-3-targeting peptide ligand. J Pept Sci 17: 763-769, 2011.

59. Yorita K, Takahashi N, Takai H, Kato A, Suzuki M, Ishiguro T, Ohtomo T, Nagaike K, Kondo K, Chijiiwa K, et al: Prognostic significance of circumferential cell surface immunoreactivity of glypican-3 in hepatocellular carcinoma. Liver Int 31: 120-131, 2011. 